\title{
Interventional Neurology: A Personal Road Map
}

\author{
Anthony J. Furlan \\ Department of Neurology, Neurological Institute, University Hospitals Case Medical Center, \\ Case Western Reserve University School of Medicine, Cleveland, Ohio, USA
}

The foundation of thrombolytic therapy for acute stroke rests on the NINDS IV tPA trial published in 1995 [1] and the PROACT II intra-arterial trial published in 1999 [2]. Based on NINDS and PROACT II, virtually all major stroke centers now routinely perform IV and IA thrombolysis in patients with acute ischemic stroke. The early road to thrombolytic stroke therapy had many twists and turns, some of which I now retravel with you in my strokemobile (fig. 1, 2).

In 1990 there were 2 major groups in the world working on stroke thrombolysis: the angiography-based group, spearheaded by Gregory Del Zoppo and funded by Burroughs Wellcome (BW), and the NINDS group led by Tom Brott and supported by Genentech. The angiographic group, of which I was a charter member, argued (sometimes vehemently) that all thrombolysis candidates must first undergo angiography to determine the site of occlusion and whether recanalization had occurred. Our seminal angiographic dose escalation study published in 1992 [3] established that the site of vascular occlusion in acute stroke was highly variable and could not be reliably determined by the clinical neurological examination. Moreover, recanalization varied by site of occlusion with only distal M3 MCA occlusion reliably opening with IV tPA.

The NINDS group made the seminal insight that time is brain (prior to 1990 almost all stroke trials used up to a 48-hour window). For the first time NINDS established a very aggressive treatment window of $<3 \mathrm{~h}$. NINDS argued that pretreatment vascular imaging information was neither feasible nor necessary. The NINDS group arrived at the final IV tPA dose of $0.9 \mathrm{mg} / \mathrm{kg}$ by performing 2 dose escalation trials which were halted when excessive brain hemorrhages occurred, i.e. the final dose of $0.9 \mathrm{mg} / \mathrm{kg}$ IV tPA was based solely on safety; recanalization rates for IV tPA were never established $[4,5]$.

In 1990, after 5 years of legal action, Genentech obtained a permanent injunction against BW tPA. The injunction was announced to our team by the CEO of BW while we were sitting in an airplane in Frankfurt, Germany, having just presented the initial results of the BW 
Fig. 1. Strokemobile, 1986. Artist's conception (Furlan).
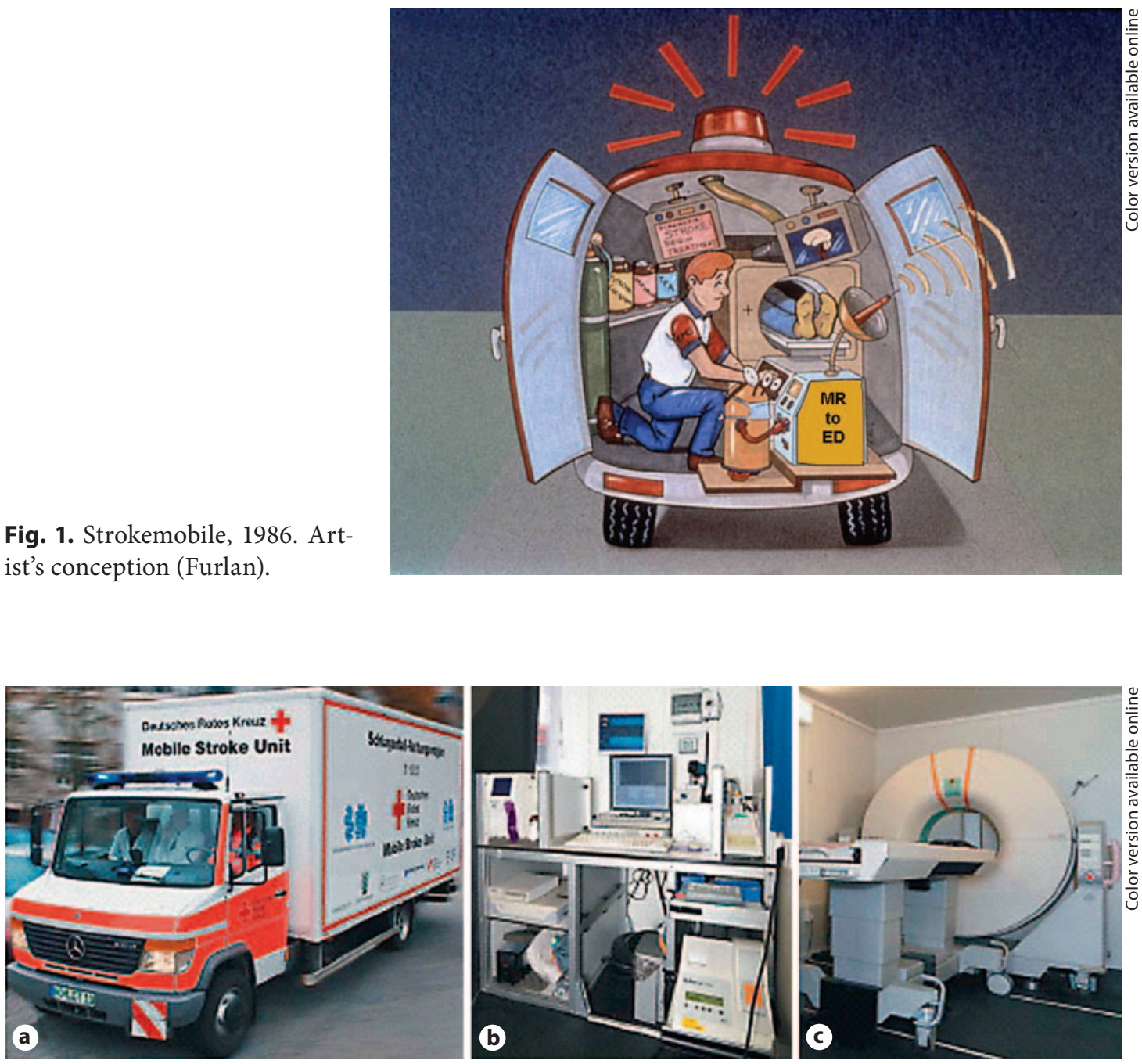

Fig. 2. Strokemobile, 2012 [17]. Homburg, Germany. a Mobile stroke unit. b Point-of-care laboratory system and telemedicine. c Portable CT scan.

tPA angiographic dose escalation trial at the first International Stroke Thrombolysis meeting in Heidelberg [6]. As a result, the BW group split into the European Cooperative Group, led by Werner Hacke, and a splinter US group led by Greg Del Zoppo, Michael Pessin, myself, and, later, Randy Higashida. The race was on.

Funded by Boehringer Ingelheim (a joint venture partner of Genentech), the European group led by Werner Hacke published the results of the first randomized controlled trial of IV tPA, ECASS I, in October 1995 (2 months before the pivotal NINDS publication) [7]. ECASS I famously used a 6-hour treatment window and an IV tPA dose of $1.1 \mathrm{mg} / \mathrm{kg}$. ECASS I failed to demonstrate efficacy but is remembered for establishing the ECASS CT criteria for early infarction - never before recognized CT criteria since we never before did CT scans so early after stroke.

Two months later, in December 1995, the pivotal NINDS IV tPA trial was published in the New England Journal of Medicine [1]. The NINDS trial led 1 year later to FDA approval of $0.9 \mathrm{mg} / \mathrm{kg}$ IV tPA within $3 \mathrm{~h}$ of stroke onset which remains the only FDA-approved therapy for acute stroke. The NINDS trial provided no data on sites of occlusion or recanalization ef- 
ficacy. It is also forgotten that the initial NINDS efficacy endpoint was a 4-point improvement in the NIHSS at $24 \mathrm{~h}$ (called the Lazarus effect) but later changed to Rankin 0-1 at 90 days.

Pari passu with ECASS I and NINDS, the US splinter group approached Genentech which agreed to fund an angiography-based dose escalation study of IV tPA called TTATTS (Thrombolytic Therapy in Thrombotic and Thromboembolic Stroke). TTATTS was stopped by Genentech at $1.0 \mathrm{mg} / \mathrm{kg}$ due to excess hemorrhages. Of note, the MCA recanalization rate was only $23 \%$. TTATTS was never published under legal threat from Genentech; the results can only be found in the Genentech FDA filing for tPA [8].

After FDA approval of IV tPA (hitherto stroke 'treatment' was heparin), the NIH sponsored the first National Symposium on the Rapid Identification and Treatment of Acute Stroke in 1996 [9] and discovered the world was not ready for 3-hour stroke therapy. At that symposium I chaired the Hospital Care of Acute Stroke Task Force which helped establish the stroke treatment time targets (without any data, mind you). Cleveland was subsequently one of the first cities to examine community use of IV tPA and reported a brain hemorrhage rate 3 times higher than that of the NINDS trial and wide variability in achieving the NINDS time targets [10]. Later the Brain Attack Coalition Primary Stroke Center and the Get with the Guidelines quality improvement criteria were developed, ultimately culminating in the ASA/Joint Commission Stroke Center Certification Process (in 2011 >700 hospitals were JCcertified primary stroke centers) [11].

Following the (quiet) collapse of TTATTS, our splinter US group decided to approach Abbott laboratories for support of a radical new idea. At that time Abbott laboratories, manufacturer of urokinase, the world's leading thrombolytic in sales but requiring large volumes of human urine, was looking to convert to genetically engineered prourokinase. Our group successfully argued that the fastest way to FDA approval was a small homogeneous intraarterial stroke trial, i.e. PROACT [12]. We argued that to demonstrate efficacy of stroke thrombolysis beyond $3 \mathrm{~h}$ (and therefore increase market potential) a more homogeneous patient population would need to be studied in order to eliminate acute stroke 'noise.' PROACT established the recanalization efficacy of IA prourokinase through a double blind sham control (IA saline into the MCA; never to be repeated). In 1999 I reported the results of PROACT II which demonstrated the clinical efficacy of IA prourokinase out to $6 \mathrm{~h}$ and remains the foundation of IA stroke thrombolysis in selected patients. Unfortunately, and although IA thrombolysis is now performed routinely in every stroke center in the world, neither prourokinase nor IA stroke thrombolysis is FDA approved. In fact Abbott, at one time the world's leading manufacturer of thrombolytics and the sponsor of PROACT II, has now completely abandoned its thrombolytic venture.

In the meantime, and despite a Europe-wide training program on how to read early CT signs of infarction, ECASS II was also negative using the NINDS outcome of Rankin 0-1 (unless the analysis was performed using PROACT Rankin 0-2) [13]. It was not until ECASS III in 2008 that my old friend Werner Hacke finally got his positive IV tPA result [14]. ECASS III managed to expand the IV treatment window from 3 to $4.5 \mathrm{~h}-18$ years of work for an hour and a half; stroke thrombolysis was not proving easy.

There have been several unanticipated outcomes from the PROACT II trial. One is the development of device-based IA thrombolysis. Shortly after PROACT II was presented I was called by POSSIS Medical claiming their device could remove clots in the MCA faster than drug. POSSIS subsequently sponsored the first stroke device clinical trial, the TIME study, which used the PROACT II protocol and a modified AngioJet ${ }^{\circledR}$ device. TIME was stopped due to excess fatalities and never published (and therefore forgotten). Ironically the first approved stroke thrombectomy device, the MERCI retriever, relied on the PROACT II control data to obtain not only FDA approval but also CMS reimbursement - endorsements denied prourokinase [15]. 
Another unanticipated result of PROACT II, and of particular relevance for this inaugural issue, was interventional neurology. Interventional neurology was born at the Wild Boar restaurant in Nashville, Tenn., USA, in February, 1999. On the evening of the PROACT II presentation at the AHA Stroke Conference I learned that neuroradiology and neurosurgery were actively negotiating joint interventional training guidelines. Randy Higashida, a co-investigator in PROACT II, leaned over at dinner and asked me if neurology would like to get involved. Larry Wechsler and I subsequently approached Fran Kittredge and the American Academy of Neurology (AAN) which formed an Interventional Neurology Task Force consisting of Larry Wechsler, Camillo Gomez, and myself. Many difficult negotiations ensued. The AAN threatened legal action if neurology was not included in the ACGME interventional negotiations. The ACGME agreed with the AAN, the radiology and neurosurgery Residency Review Committees (RRCs) acquiesced, and the ACGME approved an interventional neurology training pathway in 2001 (the official but clumsy ACGME designation endovascular surgical neuroradiology is seldom used) [16]. One final irony: as a prerequisite to interventional training, neurologists had to complete an ACGME-approved vascular neurology residency which did not exist at that time (i.e. stroke fellowships were not ACGME approved). In a classic example of the tail wagging the dog, a second AAN task force under Harold Adams was formed which completed the ACGME requirements for board certification in vascular neurology. I was told by Jasper Daube, head of the neurology RRC, that obtaining 2 new ACGME-approved residencies (vascular neurology and interventional neurology) within 2 years was a world record. The rest is history.

\section{Disclosure Statement}

Dr. Furlan has the following disclosures: PI PROACT II ABBOTT, PI DEDAS PAION, North American PI DIAS II, CO-PI TIME POSSIS MEDICAL, PI CLOSURE I NMT MEDICAL.

\section{References}

1 Tissue plasminogen activator for acute ischemic stroke - the National Institute of Neurological Disorders and Stroke rt-PA Stroke Group. N Engl J Med 1995;333:1581-1587.

-2 Furlan A, Higashida R, Wechsler L, et al: Intra-arterial prourokinase for acute ischemic stroke: the PROACT II study - a randomized controlled trial. Prolyse in acute cerebral thromboembolism. JAMA 1999;282:2003-2011.

-3 del Zoppo GJ, Poeck K, Pessin MS, et al: Recombinant tissue plasminogen activator in acute thrombotic and embolic stroke. Ann Neurol 1992;32:78-86.

4 Brott TG, Haley EC Jr, Levy DE, et al: Urgent therapy for stroke. 1. Pilot study of tissue plasminogen activator administered within 90 minutes. Stroke 1992;23:632-640.

5 Haley EC Jr, Levy DE, Brott TG, et al: Urgent therapy for stroke. 2. Pilot study of tissue plasminogen activator administered 91-180 minutes from onset. Stroke 1992;23:641-645

6 Del Zoppo GJ, Ferbert A: Intravenous recombinant tissue plasminogen activator in acute thrombotic stroke: study design, recanalization, and clinical outcome; in Hacke W, del Zoppo GJ, Hirschberg M (ed): Thrombolytic Therapy in Acute Ischemic Stroke. Berlin, Springer, 1993, pp 147-151.

7 Hacke W, Kaste M, Fieschi C, et al: Intravenous thrombolysis with recombinant tissue plasminogen activator for acute hemispheric stroke: the European Cooperative Acute Stroke Study (ECASS). JAMA 1995;274:1017-1025.

8 FDA PLA Supplement 96-0350 March 19, 1996 for tissue plasminogen activator (tPA; Activase ${ }^{\mathrm{R}}$ ) with the proposed additional indication of: 'Activase is indicated for the management of acute ischemic stroke in adults for improving functional outcome and neurological recovery and reducing the incidence of disability associated with stroke'. TTATTS, $\mathrm{p} 68$.

9 Marler JR, Winters-Jones P, Emr M (eds): Proceedings of a National Symposium on Rapid Identification and Treatment of Acute Stroke. Bethesda, NIH, 1997, No. 97-4239.

10 Katzan IL, Furlan AJ, Loyd LE, et al: Use of tissue-type plasminogen activator for acute ischemic stroke: the Cleveland area experience. JAMA 2000;283:1151-1158. 
11 Alberts MA, Hademenos G, Latchaw RE, Jagoda A, Marler JR, Mayberg MR, Starke RD, Todd HW, Viste KM, Girgus M, Shephard T, Emr M, Shwayder P, Walker MD: Recommendations for the establishment of primary stroke centers - Brain Attack Coalition. JAMA 2000;283:3102-3109.

12 del Zoppo GJ, Higashida RT, Furlan AJ, Pessin M, et al. PROACT: a phase II randomized trial of recombinant prourokinase by direct arterial delivery in acute middle cerebral artery stroke. Stroke 1998;29:4-11.

$\checkmark 13$ Hacke W, Kaste M, Fieschi C, et al: Randomised double-blind placebo-controlled trial of thrombolytic therapy with intravenous alteplase in acute ischaemic stroke (ECASS II). Lancet 1998;352:1245-1251.

- 14 Hacke W, Kaste M, Bluhmki E, Brozman M, Da'valos A, Guidetti D, Larrue V, Lees KR, Medeghri Z, Machnig T, Schneider D, von Kummer R, Wahlgren N, Toni D, ECASS Investigators: Thrombolysis with alteplase 3 to 4.5 hours after acute ischemic stroke. N Engl J Med 2008; 359:1317-1329.

15 Smith WS, Sung G, Starkman S, Saver JL, Kidwell CS, Gobin YP, Lutsep HL, Nesbit GM, Grobelny T, Rymer MM, Silverman IE, Higashida RT, Budzik RF, Marks MP: Safety and efficacy of mechanical embolectomy in acute ischemic stroke: results of the MERCI trial. Stroke 2005;36:1432-1438.

16 ACGME program requirements for graduate medical education in endovascular surgical neuroradiology. http://www. acgme.org/acWebsite/RRC_180/180_prIndex.asp.

17 Walter S, Kostpopoulos P, Haas A, Helwig S, Keller I, et al: Bringing the hospital to the patient: first treatment of stroke patients at the emergency cite. PLoS One 2010;5:e13758. 